Journal of the Scholarship of Teaching and Learning, Vol. 19, No. 5, December 2019, pp. 61-76.

doi: 10.14434/josotl.v19i5.24300

\title{
First Generation College Students' Perceptions of an Academic Retention Program
}

\author{
Lisa Schelbe \\ Florida State University \\ lschelbe@,fsu.edu \\ Martin Swanbrow Becker \\ Florida State University \\ Carmella Spinelli \\ Florida State University \\ Denesha McCray
}

\begin{abstract}
This qualitative study examines the perceptions of students enrolled in a campus-based program designed to promote academic success and retention of first generation college students. Method: Twenty-five undergraduate students in the program participated in focus groups and interviews to share their perceptions and experiences. Research team members conducted a thematic analysis on the focus groups and interviews transcripts. Findings: Students reported program components that contributed to their academic success and retention including support, expectations, resources, and preparation. Students also described concerns about how students' needs changed over time and how students in the program were perceived on campus.
\end{abstract}

Keywords: First generation college students; higher education; retention; college transition; academic success

First-generation college students are the first in their family to attend college-neither parent has attended college nor has been awarded a college degree (Padgett, Johnson, \& Pascarella, 2012; Stebleton, Soria, \& Huesman, 2014). The strengths and resiliency of first generation students cannot be overstated as many have overcome substantial obstacles to pursue higher education. In 2010, an estimated 4.5 million first generation college students were enrolled in colleges and universities in the United States (Pryor, Hurtado, DeAngelo, Blake, \& Tran, 2011). With the high number of first generation students, college and university administrations increasingly have recognized that these students face different challenges and needs when compared to their peers (Pryor et al., 2011; Reid \& Moore, 2008; Stebleton et al., 2014).

Once enrolled, first generation students are four times more likely than their peers to drop out at the end of their first year (Engle \& Tinto, 2008). This trend is not unique to the first year experience as compared to their peers with parents who graduated from college, using national data sets, first generation college students were found to be 8.5 time more likely to drop out of college during the first four years at college (Ishitani, 2006). A study also using national data found at the end of five years in higher education, first generation students are similarly less likely to have remained in college and earned a bachelor's degree than their peers (Pascarella, Pierson, Wolniak, \& Terenzini, 2004). To address this disparity, institutions have increasingly developed programs to increase the academic successes and retention of first generation college students. This study examines the perceptions of 
first generation students related to their enrollment in GenOne ${ }^{1}$, a campus-based program designed to assist first generation college students at a large southeastern university.

\section{Literature Review}

Quantitative and qualitative studies have found when compared to their peers, first generation students are more likely to come from lower socio-economic families (Choy, 2001; Soria \& Stebleton, 2012; Terenzini, Springer, Yaeger, Pascarella, \& Nora, 1996) and racial/ethnic minority backgrounds (Choy, 2001; McCarron \& Inkelas, 2006; Stebleton et al., 2014; Terenzini et al., 1996), work more hours while in school (Barry, Hudley, Kelly, \& Cho, 2009; Pascarella et al., 2004; Stebleton \& Soria, 2013; Terenzini et al., 1996), study fewer hours (Pascarella et al., 2004), and have access to fewer supportive resources (Barry et al., 2009; Padgett et al., 2012; Reid \& Moore, 2008; Stebleton et al., 2014). First generation college students also expect to rely on student loans more than their peers (Lee \& Mueller, 2014; Somers, Woodhouse \& Cofer, 2004).

First generation students begin college at a disadvantage compared to their peers in terms of social support, academic expectations, academic preparation, and access to resources (Barry et al., 2009; D’Allegro \& Kerns, 2010; D’Amico \& Dika, 2013; McCarron, \& Inkelas, 2006; Padget et al., 2012; Pascarella et al., 2004; Reid \& Moore, 2008). The transition from high school to college can be challenging for all students, however, first generation students face distinct and more challenges than their peers (Padgett et al., 2012; Reid \& Moore, 2008; Schademan \& Thompson, 2015; Stebleton \& Soria, 2013; Stebleton et al., 2014). One challenge is lack of financial resources, which sometimes contributes to students' need for employment while in school. The time commitment of employment can create challenges for first generation students (Mamiseishvili, 2010; Stebleton \& Soria, 2013) who also have the challenge of more family commitments than their peers (Lohfink \& Paulson, 2005; Stebleton \& Soria, 2013). All of the challenges, if unaddressed, potentially can disrupt this transition to college and place first generation students' academic success at risk.

First generation students, having little to no experience with college life, often begin college uncertain of what their new role as a college student entails (Pascarella et al., 2004; Reid \& Moore, 2008; Soria \& Stebleton, 2012). As compared to their peers, first generation students begin college less confident and more unfamiliar of the coursework expectations in a university environment (Barry et al., 2009; DeFreitas \& Rinn, 2013; Padgett et al., 2012; Reid \& Moore, 2008). Additionally, first generation students are less academically engaged (Pascalla et el, 2004; Pike \& Kuh, 2005; Soria \& Stebleton, 2012; Yee, 2016). First generation students tend to be unaware of the academic expectations professors hold for their students and less likely to reach out to faculty for help or assignment clarification (Soria \& Stebleton, 2012; Schademan \& Thompson, 2015; Yee, 2016). In addition to disconnected expectations, first generation students often begin college without the skills necessary to succeed academically when compared to their peers (Padgett et al., 2004; Reid \& Moore, 2008; Stebleton \& Soria, 2013). Compared to their peers, first generation students are less confident in their academic abilities (DeFreitas \& Rinn, 2013; Reid \& Moore, 2008), have a lower sense of self-efficacy (Inman \& Mayes, 1999), have lower educational aspirations (Pike \& Kuh, 2005), and received less academic preparation during high school (Atherton, 2014; Choy, 2001; Pascarella et al., 2004). For many students, parents can provide context to the challenges of rigorous coursework and developing strong study habits, but first generation students likely do not have parents or social network members who understand these requirements of college (Padgett et al., 2004; Reid \& Moore, 2008; Sy, Fong, Carter, Boehme, \& Alpert, 2011). In essence, first generation college students are disadvantaged as they lack the proper exposure or mentoring to prepare for college (Soria \& Stebleton, 2012).

${ }^{1}$ A pseudonyms is used for the program name to maintain confidentiality.

Journal of the Scholarship of Teaching and Learning, Vol. 19, No. 5, December 2019. josotl.indiana.edu 


\section{First Generation College Students' Resilience and Protective Factors}

Despite the challenges they face, first generation college students demonstrate great resilience. Research frequently is framed in a deficit model examining the individual challenges first generation students encounter (Spiegler \& Bednarek, 2013). However, many first generation students succeed in college, and understanding their resilience and strengths is important (Clauss-Ehlers \& Wibrowski, 2007). Studies examining the negative outcomes (i.e., dropping out) often fail to acknowledge that first generation students often overcome significant odds to even start college.

Social support, defined as a sense of connection, belonging, and relationship satisfaction, is identified as a protective factor in the retention of first generation students (Pascarella et al., 2004; Soria \& Stebleton, 2012; Wang, 2012). This type of support is influential in determining the level of social and academic engagement students have with their peers, college organizations, and faculty (Barry et al., 2009, Soria \& Stebleton, 2012). For first generation students, the greater the sense of social support and belonging, the less likely they are to drop out, and the more likely they are to remain in university in pursuit of graduation (Pascarella et al., 2004; Soria \& Stebleton, 2012).

Unfortunately, research has also found first generation students are less likely to engage in supportive experiences such as group study, joining student organizations, or reaching out to peers and faculty for assistance (Pascarella et al., 2004; Pike \& Kuh, 2005; Soria \& Stebleton, 2012; Yee, 2016). This may be because first generation students who work more and have more family commitments may not have the time necessary to become engaged in the activities (Lohfink \& Paulson, 2005; Mamiseishvili, 2010). While first generation students are less likely to be engaged, those who are involved in extracurricular activities derive greater benefits and outcomes from their involvement (Pascarella et al., 2004).

\section{Campus-based Programs}

Recognizing the distinct and growing needs of first generation students, institutions have developed programs geared toward improving the retention and academic success of these students. These programs can be "bridge programs" which focus on first generation students' transition to a university, supportive programs that are available to the students throughout their academic career, or a combination of these two program types. Programs that encompass initiatives aimed at developing preparatory academic skills and building strong social and academic support networks to retain first generation students increase the likelihood they will graduate (Petty, 2014; Reid \& Moore, 2008). Research has found programs for first generation college students can increase retention as well as grade point averages in the first year of college (Folger, Carter, \& Chase, 2004).

Building programs to mitigate the differences between first generation students and their peers is needed; however, without direct input from first generation students themselves, programs may not fully understand how to effectively meet student's needs, and they may not fully appreciate the relative impact specific components of these programs have on students. Currently few studies examine the experiences of first generation college students from their perspectives (Byrd \& MacDonald, 2005; Nichols \& Islas, 2015; Reid \& Moore, 2008; Stebleton et al., 2014; Swanbrow Becker, Schelbe, Romano, \& Spinelli, 2017; Yee, 2016). This study addresses this gap by examining students' perceptions in terms of how GenOne, a campus-based, first generation college student program developed to promote academic success and retention, impacted their academic performance. The study's research questions are 1) how do GenOne students perceive elements of the GenOne program as contributing to student retention and 2) how do GenOne students believe GenOne could increase student retention? 


\section{Method}

This qualitative study, conducted in collaboration with the GenOne Director and administration, is a thematic analysis of data from focus groups and interviews to examine the perceptions of students in GenOne, a first-generation student academic retention program at a large southeastern public university of approximately 40,000 students. The retention rate for the university is approximately 72 $74 \%$ and while the retention rate for GenOne students is lower at approximately $68 \%$, this difference in retention rate appears smaller as compared to those found in other studies (Engle \& Tinto, 2008; Ishitani, 2006). The goal of the GenOne program is to promote academic success and increase retention of first generation students. GenOne administration developed the research questions with the research team, who collected and analyzed the data. The Florida State University Institutional Review Board approved the study.

\section{Description of GenOne}

GenOne serves approximately 1,500 students, the vast majority of whom are African American and Latino. The mission of GenOne is to assist first generation college students' transition to and graduation from college. In this institution specific program, students are admitted to the university through the GenOne admissions process that takes into consideration the unique challenges due to educational and economic circumstances and the potential for unique contributions of individuals. The cornerstone of GenOne is the Summer Bridge Program, an intensive eight-week program that provides incoming students with orientation to the program, university, and community. During the Summer Bridge Program, staff assign each GenOne student to a small group led by an ambassador, an upper class student serving as paid peer mentor. Additionally, students connect with GenOne staff during program events and informal interactions.

The Summer Bridge Program seeks to provide experiences to help students prepare for the academic rigors of college. Students attend introductory college classes, exposing them to new, heightened academic expectations and the necessity of building new study and time management skills. Monitoring of student participation occurs through mandated study hours in a dedicated study lab that provides access to tutors and through interactions with the ambassadors.

In order to support students' social, emotional, and academic growth, students gain access to the institution's resources through shared living and programming. During the Summer Bridge Program students live in university housing and often form close bonds with their peers. They attend meetings where they are introduced to the institution's representatives and resources (e.g., counseling center, recreation facilities). They also engage in peer education programs to provide the scaffolding by which more advanced GenOne students share advice and guidance to the new students.

Following their introductory summer and throughout their first year of college, GenOne students are required to utilize study lab and log a minimum number of hours per semester starting at 10 hours, but then transitioning to between 5 and 13 hours based on their grade point average. This mandated study time seeks to help them maintain focus on academics and build effective study habits. In addition, tutors are available at the study lab to assist with English and math. Students access academic advising to assist with registering for classes and answer questions about the curriculum. Throughout the first year, students participate in monthly general assemblies where they maintain connection with GenOne students and staff, learn about events and the institution's policy, and gain access to programming to support their adjustment to college.

One of the strongest design features of the GenOne program promoted by administration is the connection with staff that is established during the summer and maintained for many throughout

Journal of the Scholarship of Teaching and Learning, Vol. 19, No. 5, December 2019. josotl.indiana.edu 
their college years. GenOne staff strongly advocate for the students and can assist them in times of need, such as when students encounter financial struggles or difficulties adjusting to college.

After successfully completing the first year of college, services are reduced. During their second year of college, individual coaching is provided to GenOne students to discuss any aspects of their life and to develop plans to achieve their goals. Coaches can help students explore issues with academics, career choice, personal development, and relationships. After the second year in GenOne, fewer structured programs are offered to students. Many students, however, choose to continue their involvement with events and may continue using the tutoring and study lab.

\section{Sample}

All study participants were involved with GenOne. A research team member introduced the study during a GenOne meeting and invited students to participate in a focus group. Additionally, a GenOne staff member e-mailed students about upcoming focus group sessions, directing all interested participants to the research team to confirm attendance. Participants consented to be interviewed about their thoughts and experiences with GenOne. Faculty members and trained graduate students worked in pairs to co-facilitate the focus groups with GenOne students and individual interviews with GenOne ambassadors. Compensation was not provided to participants; however, food and drinks were offered during the focus groups.

Faculty members and trained graduate students co-facilitated four focus groups and six interviews. Focus groups lasted between 27 and 180 minutes $(\bar{x}=71)$, while interviews lasted between 19 and 72 minutes $(\bar{x}=45)$. Study participants included 25 GenOne students, four of whom were GenOne ambassadors. Saturation was reached with the sample size, which is consistent with previous research that has reached saturation with samples of as few as a dozen participants (Padget, 2017). The final sample consisted of 19 female and six male students. Of those, 17 were first year students, three were second year students, and five were upper-class students. The students were between 18 and 22 years old with the average age of 19.1 years. Students self-reported ethnic and racial identifications as follows: 14 as African American; eight as Hispanic; two as White, and one as Other.

\section{Data Collection and Analysis}

Data were collected over a four-month period in the spring of 2014 during which time the research team conducted focus groups with GenOne students and individual interviews with Ambassadors. This project collected data through focus groups with students to incorporate perspectives from different people while providing the opportunity for reaction to comments from other participants (Braun \& Clark, 2013). Interviews were conducted with Ambassadors because interviews provided more time to ask follow-up questions and get more details (Braun \& Clark, 2013) about the Ambassadors' experiences who not only were GenOne students, but also had experiences working with other GenOne students throughout the Summer Bridge program. All focus groups and individual interviews were audio recorded and transcribed verbatim.

The research team analyzed data in accordance with the principles of representational thematic text analysis, where themes emerge directly from the data rather than from pre-determined categories. The analysis plan followed the guidelines for thematic analysis outlined by Braun and Clark (2013), which occurs over six steps: become familiar with the data; generate initial codes; search for themes; review themes; define and name themes; and produce the report. Three team members individually read and coded each transcript to identify themes related to the research questions. Following coding, team members wrote memos reflecting on the transcript contents and any themes. The team met

Journal of the Scholarship of Teaching and Learning, Vol. 19, No. 5, December 2019. josotl.indiana.edu 
regularly during the analysis process to discuss the data and through discussion reached consensus on the themes in the data.

The research team employed multiple strategies to increase the trustworthiness and rigor of the study. The study used a thematic analysis process where multiple team members coded independently and reached consensus in each step (Braun \& Clarke, 2013). The diversity of participants and multiple focus group and interviews allowed for triangulation of data. The research team's diversity also contributed to the trustworthiness of the study as the team included faculty and research assistants from different disciplines, racial identities, and genders; research assistants pursuing different levels of education (i.e., bachelors, masters, and doctoral); and one research assistant who was a first generation college student. Throughout the process, the research team regularly debriefed and engaged in reflexivity.

\section{Findings}

Students endorsed several components of GenOne that they felt directly led to their academic success and retention, including support, expectations, preparation, and resources. Support encompasses the beneficial relationships of staff, faculty, mentors, and peers. Expectations is conceptualized as having a sense of needing to be responsible in college and planning to succeed. Preparation includes personal growth and skill development attributed to the programs that assisted with their transition to college. Resources include tools, institution connections, and financial assistance.

When asked about their ideas for how GenOne could better serve students and increase retention, students consistently emphasized their desire for GenOne to continue to provide services past the early college years. Two areas that were highlights as opportunities for improvement included attending to the changing needs of GenOne students over the course of their academic careers and addressing campus perceptions and reducing stigma faced by the first generation college students.

\section{Support}

Students most frequently attributed their connection to GenOne staff and ambassadors as the strongest factor impacting their transition to college. A common theme emerging from the data suggests that those students able to form these connections continued to access them throughout college experience. Some students found value in having developed a relationship with someone in GenOne to reach out to in times of need but also someone who may check in on them periodically. One student explained about GenOne staff, "[T]hey really believe in your dreams so whenever you have something that you need help in or something that you want to do to help you with your future, they really support you." Often while discussing support, students mentioned having a similar background or shared common interests with staff members they accessed, such as belonging to the same sorority or fraternity.

Students report that the strong personal connections developed through GenOne lead them to feeling part of the GenOne "family." One student shared, "It was really a family. It wasn't just a program." Students frequently noted that at times they felt like they may have to leave college due to various circumstances, but they persisted because they did not want to let down GenOne staff, their ambassador, and their peers. A student explained, "It was almost like [staff] were a parent figure. And it was like we don't want to let you down because you brought us in. Why would we put you to shame?" One student described GenOne as "my home away from home."

Students were clear that while GenOne contributed to their successes, support became critical to their retention during a crisis. One student shared about her previous semester: 
I was failing two or three of my classes. And I was going through a lot emotionally and I was in counseling. And I think that [staff] pulling the student aside-which is what they did with me-and talking through it and giving me an action plan to execute and meeting up again to check in really helps. And that's definitely what kept me here and what's keeping other people here.

While such connection served many students, the data suggest it had a differential impact for those students not able to form solid connections with ambassadors or staff early on. In these cases, students tended to get "lost." For students who ask GenOne for help, their connections to people served them well in terms of acquiring support. Those not asking for help, however, were not tracked by GenOne; staff did not know these students needed support and consequently a subset of students who may need help were less likely to find support. An exception is a program within GenOne for former foster youth. Students in this program had regular meetings and check-ins from a dedicated GenOne staff member throughout their time at the university.

\section{Expectations}

Many GenOne students reported that as the first in their families to attend college, they lacked role models for academic success and GenOne filled this gap through providing role models and expectations for students that promoted accountability. Many ambassadors and staff had experienced similar struggles as the students and persevered, which students said was both motivating and also helped form interpersonal connections. Several participants discussed how, as students experienced hardships and considered leaving the university, staff both inspired them and reminded them about the importance of education. Students describe a culture of success where GenOne staff maintain the belief that students should remain at school despite hardships they may encounter. "They don't let you go easy," one student said referring to GenOne staff discouraging students from leaving school. Students were clear that while there was support and resources available to assist students, ultimately students were accountable for their success and staying in school. On student summed this up, "It's on you." Such clear articulation of responsibility appeared to help students focus on their goal of succeeding in college.

Students discussed how staff held them to high standards and challenged them to succeed, as is evident in one student's remark:

I know stepping out of my comfort zone was something good for me. But [GenOne] pushed me to be more vocal and meet new people and join organizations. So that is what I did. I'm grateful that they did push me to do that.

Students explained the staff's high expectations and holding them accountable often filled a gap in their lives as their family members and cultural expectations from their home communities did not consistently demand the same excellence.

Mandatory study hours and monthly general assemblies helped provide structure and clear expectations for students to focus on their academics. Many students confessed they while they had not fully developed the skills or habits in high school to manage their time in a way where they could handle the academic rigors of college, they also had not understood the expectations to do so. The standards of higher education were not clear to them prior to coming to college, and students reported feeling ill-prepared to meet the expectations to succeed. The Summer Bridge Program offered a nurturing, yet rigorous, introduction to college and helped set new expectations. The ongoing

Journal of the Scholarship of Teaching and Learning, Vol. 19, No. 5, December 2019. josotl.indiana.edu 
programing and relationships with staff then reinforced the expectations.

\section{Preparation}

The Summer Bridge Program was almost synonymous with GenOne for many of the students who talked about how being in the program helped their transition to college. One student explained:

It really, like, helped me feel comfortable. And all the information helped me build my confidence and going through the, I mean, having the [GenOne study] lab hours and stuff like that... helped me academically... it just helped me feel way more confident in myself...

Further, by living together in university housing during the Summer Bridge Program, students were able to practice more independent living within a supportive structure. Students noted that mandatory study hours with tutors available assisted them in developing time management and study skills to help them adjust to the academic rigors of college. A student explained, "Although the university [helps] during orientation, I felt that GenOne did a great job of making [orientation] on a more of a personal level." Students repeatedly disclosed that GenOne helped prepare them in terms of personal growth and skill development for the rigors of college, which ultimately helped them succeed and stay in school.

\section{Resources}

Access to and knowledge of resources provided another aspect of GenOne that students reported as instrumental to their ability to thrive academically and socially. Summer Bridge Program and general assemblies throughout the first year exposed students to resources such as the counseling center, financial aid office, academic advising, and dean of students office, helping them with assimilation into their new environment. A student explained, "[GenOne] really did put resources out there for me and guided me in the right direction." Student reported that access to these resources helped them engage in healthy behaviors (e.g., healthy eating, exercise) and also access resources more quickly in times of need (e.g., counseling, advising). Scholarships and grants were specifically mentioned as resources that helped students remain in school.

Further, students experiencing a significant hardship, often described as financial troubles at home and academic concerns, reported GenOne staff made significant contributions to helping them resolve their issues. GenOne staff would often advocate for students across the institution and connect students with important resources, such as the Dean of Students Department and Financial Aid. A student commented that GenOne staff "moves mountains for us" when students needed help. Another explained, "They go above and beyond if you need anything." Students routinely shared that they received help when they were in crisis. One student explained,

[staff] gave us all the tools to do it and if we wanted...we could get help. That's just the initiative of the student, they already have told us like, "Here this is how you get help. Here is where you go. like, this is where you can go to talk about it."

Students believed the connection to the resources along with the assistance from GenOne staff significantly contributed to their retention.

\section{Opportunities for Improvement}

Journal of the Scholarship of Teaching and Learning, Vol. 19, No. 5, December 2019. josotl.indiana.edu 
When students were asked about how GenOne could better assist first generation college students, they most frequently suggested extending the current program offered beyond the early college years. Students expressed a desire for continued connection to the program and for the ambassadors to continue their support throughout their first year and into their second year. Similarly, students requested the programing continue throughout their college career. While most discussions about how GenOne could improve were positive, there were some concerns raised, specifically regarding how GenOne students' needs changed over time and how GenOne students were perceived across the institution.

Attend to Changing Needs. One concern expressed by students lies in the shifting needs of students as they progress through college. Following the intensive Summer Bridge Program, primary support from GenOne shifts to monthly general assemblies, mandated study hours, tutors, and academic advising over the first year. With the second year those supports generally drop off. Support in the junior and senior years was available upon request, but no formal support was in place.

GenOne provides intensive support to aid in student transition to college, especially through the Summer Bridge Program and the first year with the required study hours and general assemblies. The shift from the intensive support being provided with mandatory program to support being offered at students' initiative was jarring for some. One student described this:

[GenOne] just kinda push you out of the nest, like they expect you to fly... I felt like they were there all the time. And then all of a sudden, they were just gone. And it was like, "Okay, now it is your responsibility."

As their college career progressed, students had to be more proactive to stay connected.

In the second year, students endorsed having more existential needs, such as finding a major, thinking about a career, managing increasing independence and responsibilities, and more generally transitioning into adulthood. Coaches were available to those students who choose to take advantage of such resources, but more structured programming directed to all students and these particular developmental needs may help the broader group, students explained. Students stressed that having ambassadors continue throughout the first and second year would be helpful; although several also acknowledged that ideally the ambassadors would be compensated for their assistance.

Students reflected that the needs for access to resources and support from GenOne continued after the first and second year. One student shared, "And I understand that there is a lot of things that go on in life, and I understand that you can't continue to keep getting babied, but to some extent we're going to need that information." There was the general consensus that throughout college, students would benefit from GenOne programs. One student summed up the general consensus that there was a need to implement a "more aggressive approach to getting students to be active [in GenOne] after their freshman and sophomore year" because "after your freshman and sophomore year, you do have a different mindset, not only about school but about a lot of things."

In the final year of college, students expressed needing help with managing their career search and deciding whether to attend graduate school. Students described how they wished GenOne would attend to the changes needs of students as they progress through their studies. Several students in different focus groups mentioned ideally GenOne would continue for students who pursued advanced degrees in graduate schools.

Students expressed a desire for continued support throughout their time in college and GenOne to address the changing needs of students. However, they quickly emphasized that they did not want to feel "babied" and were conflicted about making any programs mandatory. Students expressed wanting to have freedom in choosing to be involved in GenOne throughout college, yet

Journal of the Scholarship of Teaching and Learning, Vol. 19, No. 5, December 2019. josotl.indiana.edu 
some pointed out the issue that that optional programs may not be fully utilized. A student explained, "I feel like making [programs for juniors and seniors] mandatory would help...I know for certain people, they are like, 'oh, it's not mandatory, so I am not showing up."' Indeed, one student reflected:

Once you hit the junior year [general assemblies and study hours] aren't mandatory anymore, but they are still helpful if you chose to go... It's not up to [GenOne] if you want to go or not, but they are giving you the option. So they are putting that resource out there. It's your fault if you take advantage of it or not.

This tension between wanting support, yet not having mandatory programming was throughout students' responses about how GenOne could better serve students.

Addressing Campus Perception. Students endorsed a deep sense of pride in being part of GenOne. One student stated this strongly: "I may not always bleed [the university's colors], but if you cut me I will bleed [GenOne]. That is just what it is." Along with the sense of pride and identity was an acknowledgement of a stigma at the institution regarding GenOne students, with some saying that they felt GenOne students were perceived as not belonging at the institution due to the alternative admission criteria and as being "babied" with the extra resources and support available to them.

The alternative admission criteria used by GenOne meant that on average high school grade point averages and standardized test scores of GenOne students were lower than that of the institutions' general student body. Students described how others believed that the alternative admission criteria translated to GenOne students not seen as being legitimate students on campus. Several students described overhearing conversations about GenOne students where other students called GenOne students "dumb" and said "[GenOne students] are not supposed to be here." One student described defending the alternative criteria of GenOne and responded, "There's some bright people [at GenOne]. It's just we didn't get in the same way you did."

GenOne students were adamant that they belonged at the institution and defended their admission due to the circumstance related to their being first generation students. One student shared, "I didn't get in [to the institution] on my SAT or ACT scores because I had a hard time paying for it." Despite their belief that they belonged at the institution, GenOne students found the stigma and perceptions of GenOne taxing. One student explained:

It's very hard being a [GenOne] student because not only are people like... "How'd y'all get into that program?", "Oh so y'all got in the easy way?", and stuff like that... and a lot of those people are saying "Oh, you only got into [university] because of [GenOne]."

GenOne students emphasized that consistently grade point averages of GenOne students were equal to those of their peers at the university. Likewise, students mentioned GenOne students disproportionately were student leaders in camps groups.

Stressing the majority of GenOne students were African American and Latino, students across multiple focus groups emphasized the perception of not belonging at the institution was also racially and ethnically influenced. One student explained, "It's a very crude message that I hear from people...people have this perception that [GenOne]'s an ethnic-based like group organization rather than just being something that helps with people that didn't have the chance." Many students described there was a negative stereotype about GenOne only being for African America students who were not qualified to be at the institution. Specifically, a few students emphasized that the university was a predominantly white institution and explained that they experienced racism on campus. Some of the racism faced was related to the stigma of GenOne and doubting the academic

Journal of the Scholarship of Teaching and Learning, Vol. 19, No. 5, December 2019. josotl.indiana.edu 
abilities of people of color. One student explained:

The connotation of [GenOne] is that it is for African American students and that is the only way they can get into college...people see it as [GenOne] is the only way Black people can get into this institution and that's not the only way it is. But [GenOne] helps our voice be recognized.

This student emphasized that while the stigma of GenOne impacted him, overall the program also assisted him and other students of color. Another student shared a similar point, "When I first got here, the race and discrimination and the things that were said, they just got to me... [GenOne] taught you how to deal with it and cope with it." Thus, despite the stigma and discrimination, students frequently credited GenOne for helping address the problems.

Another part of the stigma GenOne students experienced was connected to the support GenOne provided. Several students from multiple focus groups explained a history of nurturing the GenOne students led to the informal label of "[GenOne] Babies," a reference to a belief that GenOne students are overly nurtured and provided with resources not available to other students. Connected to this stereotype was that the students would not be able to attend the institution without extensive support as they did not truly belong there. Students recommended marketing the program to the broader institution to help the university community better understand the value of GenOne students and work to establish a more positive image to the program. One student emphasized, "[GenOne] is doing all they can to put us out there, but the university could give us the publicity that we need." Students described a desire for publicizing facts about GenOne students' grade point averages being equal to their peers at the institution and their involvement as student leaders. Likewise, GenOne students wanted their successes to be highlighted as examples of how first generation students can thrive. It was important to students that the stereotype of being "babied" was dismantled. Other students suggested increased attention to the balance between nurturing students and challenging them may help such programs address concerns of stigma and facilitate student growth.

\section{Discussion}

The insights provided by GenOne students informs thinking about how programs may better serve first generation college students. As previous studies of first generation college students have found, GenOne students faced obstacles to remaining in school. Social support, which studies have found to be a protective factor for first generation students to remain in school (Pascarella et al., 2004; Pike \& Kuh, 2005; Soria \& Stebleton, 2012; Wang, 2012), that students received through GenOne was invaluable and they perceived it to be central to their success in education. Connecting to their peers provided a sense of family, as Jehangir (2009) found. Similar to findings in other studies (e.g., Pascarella et al., 2004; Reid \& Moore, 2008; Soria \& Stebleton, 2012), GenOne students reported guidance and assistance in transitioning to college and understanding the culture and expectations for college students assisted them academically.

Research consistently has found that first generation students face use unique challenges during the transition to college (Padgett et al, 2012;Reid \& Morre, 2008; Schademan \& Thompson, 2015; Stebleton \& Soria, 2013; Stebleton et al., 2014) and campus support programs can assist with the transition (e.g., Folger, Carter, \& Chase, 2004). The transition to college was not the only time that GenOne students identified as needing support. They emphasized their needs changed throughout their college careers and it would be beneficial to have ongoing support and different resources as their needs changed. For example, approaching graduation, students may benefit from assistance in job searching or applying to graduate school.

Journal of the Scholarship of Teaching and Learning, Vol. 19, No. 5, December 2019. josotl.indiana.edu 
The GenOne students' desire for continued programs and support was somewhat internally inconsistent. They were adamant that while they wanted additional support, they did not want programs to be mandatory. This is despite their recognition that upper class students could still participate in the general assemblies, study hours, and other programs after their sophomore year, yet few did. Students explained this suggested students likely would only would participate if programs were mandatory.

Students expressed concern about the stigma they faced in terms of the alternative admission criteria and being perceived as being "babied" by GenOne. They did not want their peers to see them as unworthy or believe that GenOne students were only successful because of the extra support they received. The frustration with stigma was inherently connected to racism and discrimination as the majority of GenOne students were African American and Latino.

The concerns GenOne students raised about stigma and the discrimination they faced and some of the internal inconsistencies and ambiguity could potentially be understood better considering the impact stereotypes (Aronson \& Inzlicht, 2004) and stigma (Brown \& Lee, 2005) have been found to have on academic performance. Stereotype vulnerability, the tendency to be influenced by negative stereotypes about one's social group(s) can impact students' academic self-knowledge and performance (Aronson \& Inzlicht, 2004). Likewise, in one study, compared to white and Asian students, Black and Hispanic students experiencing stigma with high levels of consciousness about stigma have been found to have lower grade point averages although there was no difference in grade point averages found in Black and Hispanic students those with low levels of consciousness about stigma (Brown \& Lee, 2005). GenOne students intuitively seemed to be aware that the stigma and stereotypes they faced potentially negatively impacted them.

\section{Implications}

These findings support a call for institutions to consider providing resources to further academic retention throughout the college years and to tailor those resources to the emerging needs of first generation students as they shift from transitioning from high school to college to preparing for graduation. Admission of first generation college students and getting them to campus is only the beginning. Developing the presence of broad support for these students and opportunities for strong relationships with faculty, staff, mentors, and other students is paramount. Students noted that the personalized attention they received helped them feel like part of a family, but to provide such focus programs must have sufficient staff to attend to student's needs and also track students who do not proactively seek support. Relatedly, staff must balance the provision of support with a focus on encouraging student growth and resiliency by providing enough, but not too much help. Students must also have a clear understanding of the expectations for them as college students as they may not have had family members and friends who can provide appropriate guidance. Preparing first generation colleges students to be successful can be accomplished through fostering their personal growth and skill development. Additionally, programing can focus on helping first generation students' transition to institutions through connecting them with resources at the institution and in the community as well as financial assistance.

When designing and implementing programming for first generation students, their unique and changing needs as well as the larger institutional context should be taken into consideration. The needs of first generation students who are transitioning to an institution are markedly different than those of first generation students who are later in their studies or who are planning to graduate. Throughout their academic careers first generation students benefit from support and services, yet it is important to tailor programs to the students' specific needs. While focusing first generation students' transition to campus is central to retention, programs should meet their needs later in their studies

Journal of the Scholarship of Teaching and Learning, Vol. 19, No. 5, December 2019. josotl.indiana.edu 
including major selection, career planning, and professional development. The needs of students change throughout their college careers and programs need to ensure that upper class students continue to be supported and have access to resources that will help them graduate and transition post-graduation.

As first generations students are disproportionally from racial and ethnic minority backgrounds, programs should take into consideration the stigma and racism that students may face. This is especially the case as predominately white institutions. There may be campus perceptions and negative stereotypes that need to be addressed at an institutional level to ensure that the environment is conducive for first generation students. Institutions should seek to ensure that all students on campus can complete their studies in an environment free from stigma and discrimination. Reducing these stressors and barriers can contribute to students' successes.

This study is limited by the small convenience sample, which was interviewed at only one time point. Nevertheless, the study makes a significant contribution to the literature by examining the perceptions and experiences of first generation college students receiving services. In particular, this study highlights components of academic retention programs that students find most impactful to further their development and help them thrive in college. Additionally, it outlines potential areas which programs can address to improve serving to first generation college students. Future research may wish to examine not only retention, but a holistic view of the experiences of first generation college students in programs such as GenOne. It may be useful to consider differences in race and gender as well as students' experiences before college. Similarly, it may be important to study stigma and experiences of discrimination that first generation students face, especially students of color. Future research could also follow first generation college students after graduation to determine longterm outcomes stemming from academic retention programs such as this.

\section{Conclusion}

Overwhelmingly, the students attributed their success and retention to the support, expectations, preparation, and resources that they received through the GenOne program.

Enrolling first generation students is only the first steps to helping them succeed. Institutions must focus on supportive programing for first generation student throughout their time in college, building a sense of community, providing mentoring, and helping students develop skills to meet their higher expectations. Through understanding the experiences of first generation college students, universities can promote college retention and also holistic personal and professional development.

Journal of the Scholarship of Teaching and Learning, Vol. 19, No. 5, December 2019.

josotl.indiana.edu 


\section{References}

Aronson, J., \& Inzlicht, M. (2004). The ups and downs of attributional ambiguity: Stereotype vulnerability and the academic self-knowledge of African American college students. Psychological science, 15, 829-836.

Atherton, M. C. (2014). Academic preparedness of first-generation college students: Different perspectives. Journal of College Student Development, 55, 824-829. https://doi.org/10.1353/csd.2014.0081

Barry, L. M., Hudley, C., Kelly, M., \& Cho, S. (2009). Differences in self-reported disclosure of college experiences by first-generation college student status. Adolescence, 44, 55-68.

Braun, V. \& Clarke, V. (2013). Successful qualitative research: A practical guide for beginners. Thousand Oaks: Sage.

Brown, R. P., \& Lee, M. N. (2005). Stigma consciousness and the race gap in college academic achievement. Self and Identity, 4, 149-157.

Byrd, K. L., \& MacDonald, G. (2005). Defining college readiness from the inside out: Firstgeneration college student perspectives. Community College Review, 33, 22-37. https://doi.org/10.1177/009155210503300102

Choy, S. (2001). Students whose parents did not go to college: Postsecondary access, persistence, and attainment. In: National Center for Education Statistics, editor. The condition of education (pp. xviii-xliii; NCES publication no. 2001-072). Washington, DC: U.S. Government Printing Office.

Clauss-Ehlers, C. S., \& Wibrowski, C. R. (2007). Building educational resilience and social support: The effects of the educational opportunity fund program among first-and second-generation college students. Journal of College Student Development, 48, 574-584. https://doi.org/10.1353/csd.2007.0051

D'Allegro, M. L., \& Kerns, S. (2010). Is there such a thing as too much of a good thing when it comes to education? Reexamining first generation student success. Journal of College Student Retention: Research, Theory \& Practice, 12, 293-317. https://doi.org/10.2190/CS.12.3.c

D'Amico, M. M., \& Dika, S. L. (2013). Using data known at the time of admission to predict firstgeneration college student success. Journal of College Student Retention: Research, Theory \& Practice, 15, 173-192. https://doi.org/10.2190/CS.15.2.c

DeFreitas, S. C., \& Rinn, A. (2013). Academic achievement in first generation college students: The role of academic self-concept. Journal of the Scholarship of Teaching and Learning, 13(1), 57-67.

Engle, J., \& Tinto, V. (2008). Moving beyond access: College success for low-income, firstgeneration students. Washington, D.C.: The Pell Institute.

Folger, W. A., Carter, J. A., \& Chase, P. B. (2004). Supporting first generation college freshman with small group intervention. College Student Journal, 38, 472-476.

Inman, W.E., \& Mayes. L. (1999). The importance of being first: Unique characteristics of first generation community college students. Community College Review, 26, 3-22. https://doi.org/10.1177/009155219902600402

Ishitani, T. T. (2006). Studying attrition and degree completion behavior among first-generation college students in the United States. Journal of Higher Education, 77, 861-885. https://doi.org/10.1353/jhe.2006.0042

Jehangir, R. R. (2009). Cultivating voice: First-generation students seek full academic citizenship in multicultural learning communities. Innovative Higher Education, 34, 33-49. https://doi.org/10.1007/s10755-008-9089-5

Lee, J., \& Mueller, J. A. (2014). Student loan debt literacy: A comparison of first-generation and 
continuing-generation college students. Journal of College Student Development, 55, 714-719. https://doi.org/10.1353/csd.2014.0074

Lohfink, M. M., \& Paulsen, M. B. (2005). Comparing the determinants of persistence for firstgeneration and continuing-generation students. Journal of College Student Development, 46, 409428. https://doi.org/10.1353/csd.2005.0040

Mamiseishvili, K. (2010). Effects of employment on persistence of low-income, first-generation college students. College Student Affairs Journal, 29, 65-74.

McCarrron, G.P., \& Inkelas, K.K. (2006). The gap between educational aspirations and attainment for first-generation college students and the role of parental involvement. Journal of College Student Development, 47, 534-549. https://doi.org/10.1353/csd.2006.0059

Nichols, L., \& Islas, Á. (2016). Pushing and pulling emerging adults through college: College generational status and the influence of parents and others in the first year. Journal of Adolescent Research, 31, 59-95. https://doi.org/10.1177/0743558415586255

Padgett, D. K. (2017). Qualitative methods in social work research (3th ed.). New York: Sage.

Padgett, R.D., Johnson, M.P., \& Pascarella, E.T. (2012). First-generation undergraduate students and the impacts of the first year of college: Additional evidence. Journal of College Student Development, 53, 243-266. https://doi.org/10.1353/csd.2012.0032

Pascarella, E.T., Pierson, C.T., Wolniak, G.C., \& Terenzini, P.T. (2004). First-generation college students: Additional evidence on college experiences and outcomes. The Journal of Higher Education, 75, 249-284. https://doi.org/10.1353/jhe.2004.0016

Petty, T. (2014). Motivating first-generation students to academic success and college completion. College Student Journal, 48, 257-264.

Pike, G. R., \& Kuh, G. D. (2005). First-and second-generation college students: A comparison of their engagement and intellectual development. The Journal of Higher Education, 76, 276-300. https://doi.org/10.1080/00221546.2005.11772283

Pryor, J. H., Hurtando, S., DeAngelo, L., Blake, L .P., \& Tran, S. (2011). The American freshman: National norms fall 2010. Los Angeles: Higher Education Research Institute, UCLA.

Reid, M.J., \& Moore, J.L. (2008). College readiness and academic preparation for postsecondary education: Oral histories of first-generation urban college students. Urban Education, 43, 240 261. https://doi.org/10.1177/0042085907312346

Schademan, A. R., \& Thompson, M. R. (2015). Are college faculty and first-generation, low-income students ready for each other?. Journal of College Student Retention: Research, Theory \& Practice. https://doi.org/10.1177/1521025115584748

Somers, P., Woodhouse, S. R., \& Cofer Sr, J. E. (2004). Pushing the boulder uphill: The persistence of first-generation college students. NASP A Journal, 41(3), 418-435. https://doi.org/10.2202/0027-6014.1353

Soria, K.M., \& Stebleton, M.J. (2012). First-generation students' academic engagement and retention. Teaching in Higher Education, 17, 673-685. https://doi.org/10.1080/13562517.2012.666735

Spiegler, T. \& Bednarek, A. (2013). First-generation students: what we ask, what we know and what it means: an international review of the state of research. International Studies in Sociology of Education, 23, 318-337. https://doi.org/10.1080/09620214.2013.815441

Stebleton, M., \& Soria, K. (2013). Breaking down barriers: Academic obstacles of first-generation students at research universities. Learning Assistance Review, 17, 7-19.

Stebleton, M.J., Soria, K.M., \& Huesman, R.L. (2014). First-generation students' sense of belonging, mental health, and use of counseling services at public research universities. Journal of College Counseling, 17, 6-20. https://doi.org/10.1002/j.2161-1882.2014.00044.x

Sy, S. R., Fong, K., Carter, R., Boehme, J., \& Alpert, A. (2011). Parent support and stress among first-generation and continuing-generation female students during the transition to 
college. Journal of College Student Retention: Research, Theory \& Practice, 13, 383-398. https://doi.org/10.2190/CS.13.3.g

Swanbrow Becker, M., Schelbe, L., Romano, K., \& Spinelli, C. (2017) Promoting first-generation college students' mental wellbeing: student perceptions of an academic enrichment program. Journal of College Student Development, 58, 1166-1183.

Terenzini, P. T., Springer, L., Yaeger, P. M., Pascarella, E. T., \& Nora, A. (1996). First-generation college students: Characteristics, experiences, and cognitive development. Research in Higher Education, 37, 1-22. https://doi.org/10.1007/BF01680039

Wang, T.R. (2012). Understanding the memorable messages first-generation college students receive from on-campus mentors. Communication Education, 61, 335-357. https://doi.org/10.1080/03634523.2012.691978

Yee, A. (2016). The unwritten rules of engagement: Social class differences in undergraduates' academic strategies. The Journal of Higher Education, 87, 831-858. 